\title{
Is the Magyarmecske telluric conductivity anomaly a buried impact structure?
}

\section{Tamás Bodoky}

Eötvös Loránd Geophysical Institute of H ungary, Budapest

U niversity of M iskolc, Chair of Geophysics, M iskolc

\section{György Don}

Geological Institute of H ungary, Budapest

Márta Kis, István Kummer, Károly Posgay, László Sõrés

Eötvös Loránd Geophysical Institute of H ungary,

Budapest

\begin{abstract}
A more or less circular high-amplitude telluric conductivity anomaly is located at Magyarmecske, in southwestern Hungary. The authors collected and reinvestigated all available geophysical data previously measured in the area; based on this information it was concluded that the conductivity anomaly may well be explained as a buried impact crater. It is assumed that when the impact occurred, the target area was covered by a thick, coal-bearing Carboniferous sedimentary sequence. The projectile created a complex impact crater in these deposits, of a diameter of approximately 6-8 $\mathrm{km}$. In the neighborhood of the crater the coal was modified by the impact's heat and pressure. Later the impact structure was partly eroded, partly deformed by younger tectonic movements, and covered by Neogene sediments of strongly variable thickness.
\end{abstract}

Key words: impact crater, impact structure, conductivity anomaly

\section{Introduction}

The telluric map of West Hungary was published in the Geophysical Transactions of the Eötvös Loránd Geophysical Institute of Hungary, in a double issue edited by Nemesi (2000). In Chapter 5 of this paper, some peculiar Transdanubian telluric conductivity anomalies (CA) are pointed out and described in detail. One of the highlighted anomalies is the one at Magyarmecske, located about $20 \mathrm{~km}$ SE of Szigetvár (Fig. 1). Here, within a more or less circular area, the conductivity abruptly changes by more than an order of magnitude, in sharp contrast to the background. The anomaly was described for

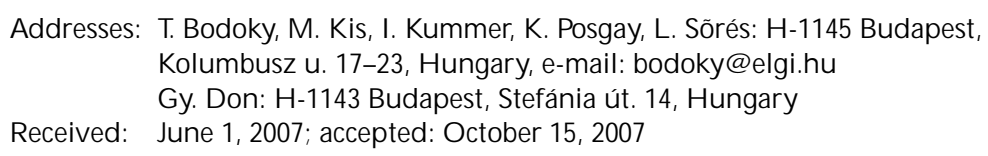




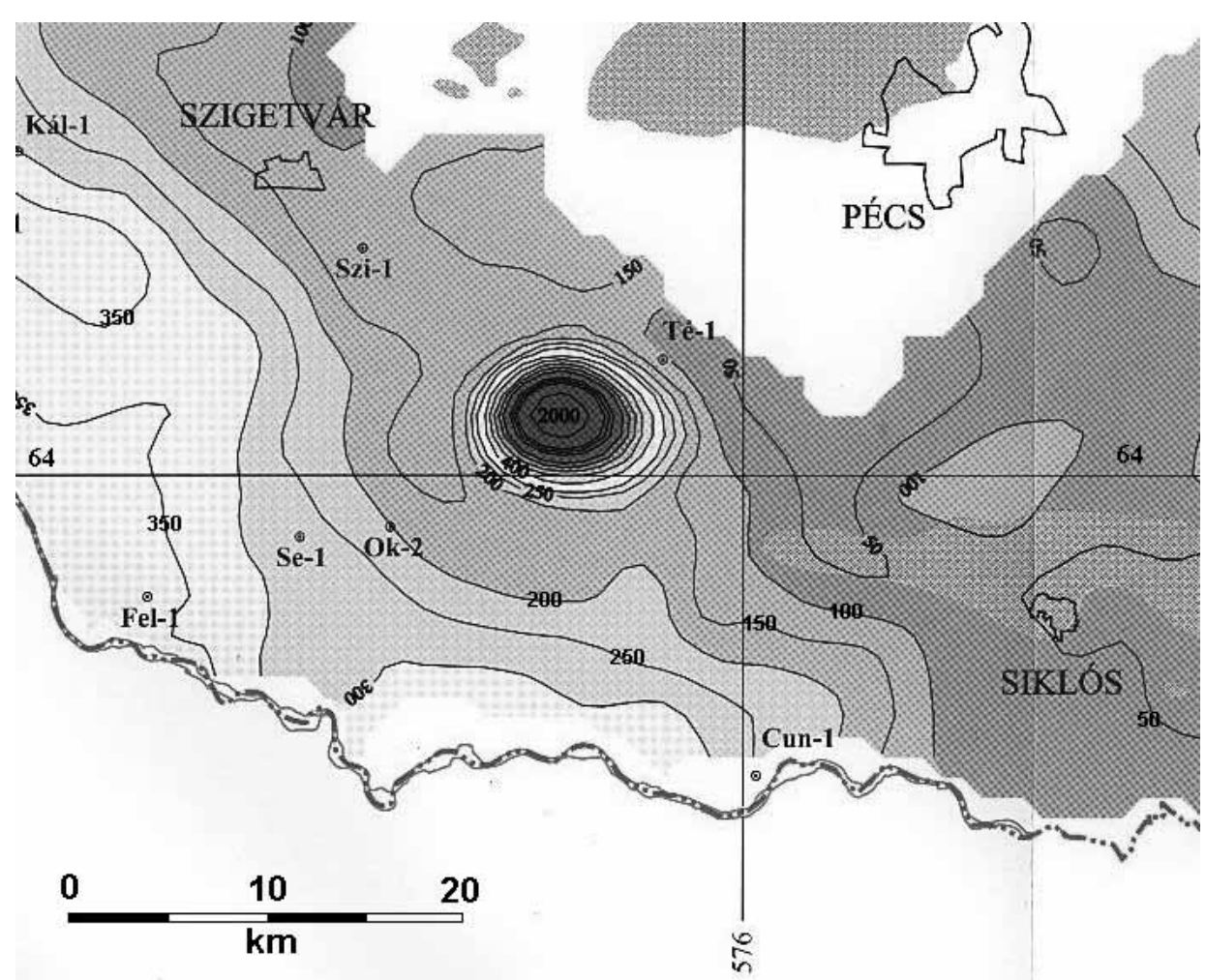

Fig. 1

Telluric conductivity anomaly at Magyarmecske on the Telluric Conductance Map of Transdanubia (Nemesi et al. 2000)

the first time in a report of the Eötvös Loránd Geophysical Institute by Varga (1977). In the report Varga attempted to provide a geologic interpretation of the anomaly as well. In 1980, referring to Varga, Ádám mentioned the anomaly and its interpretation in a comprehensive review (Ádám 1980). Since then the Magyarmecske telluric CA has appeared several times in literature in different contexts, but with a practically unchanged interpretation ( $N$ emesi et al. 1985; Ádám et al. 1990; Nemesi et al. 2000).

Nemesi et al. indicated that the anomaly is linked to a funnel-like depression of the basement, and inferring from data of the boreholes of the wider surroundings, that it is in all probability filled with a thinly-layered Carboniferous meta-anthracite sequence responsible for the conductivity anomaly (Fig. 2). They mention that the depth of the high-velocity seismic refraction basement and that of the high-resistivity geoelectric basement differ significantly from one other; the difference can be as large as $2 \mathrm{~km}$ in the center of the anomaly. On the other hand, the seismic velocities of the refracting basement decrease by $15-20 \%$ in the area of the anomaly. 


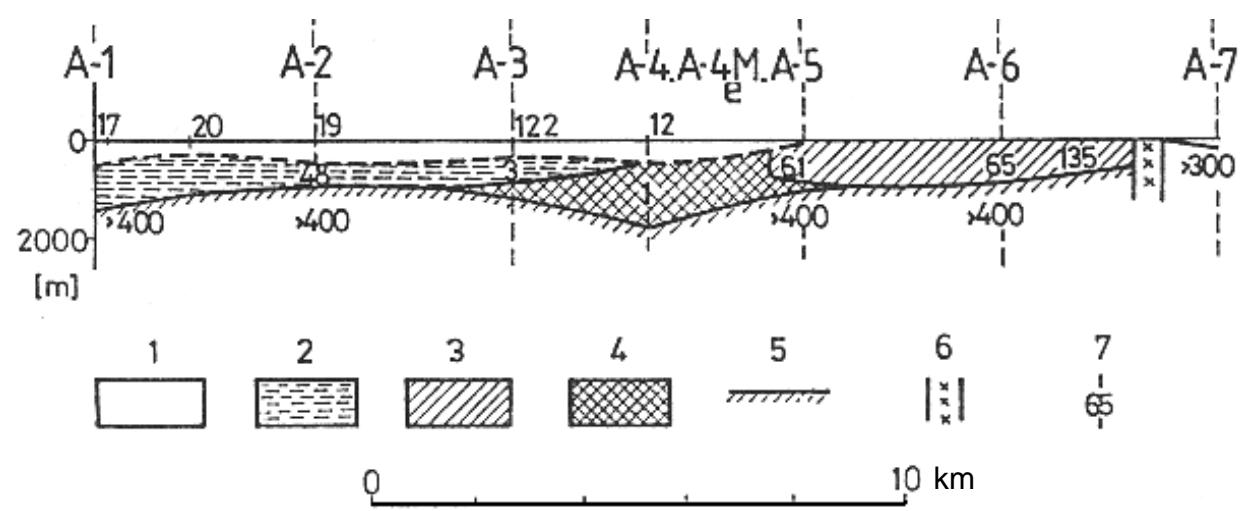

Fig. 2

Geologic interpretation of the Magyarmecske telluric conductivity anomaly, based on the A-1-A-7 MT profile (Ádám et al. 1990); 1. Upper Pliocene and Pleistocene formations (12-20 $\Omega \mathrm{m}$ ); 2. Lower Pliocene formations $(4.8 \Omega \mathrm{m}) ; 3$. Carboniferous formations of high resistivity $(61-135 \Omega \mathrm{m}) ; 4$. Carboniferous formations of low resistivity $(1 \Omega \mathrm{m}) ; 5$. Early Paleozoic crystalline basement $(>400$ $\Omega \mathrm{m}) ; 6$. Tectonic zone; 7. Resistivity of geoelectric layer calculated by 1-D MT inversion

Concerning the interpretation of the Magyarmecske telluric CA, several questions have arisen. Majoros (2000) pointed out that the coal-bearing Carboniferous sequence extends eastward far beyond the area of the anomaly, and questioned why it does not cause any similar anomaly beyond the funnellike basement depression. The Varga model provides no answer to this, nor does it explain what caused the funnel-like depression or the anomaly-related decrease of seismic refraction velocities. The extremely high values of the Magyarmecske telluric CA also require explaining. Ádám attributes them to graphitized Carboniferous coal beds (Ádám 1980); however, again this does not address the issue of why this graphitization occurred only in this one area.

In the following an attempt is made to give a new interpretation to the Magyarmecske telluric CA, namely, after reinvestigating all available geophysical data, it is proposed to explain it as the buried impact crater of a large cosmic body. It will be shown that with such an impact theory, the above-mentioned issues can be answered without raising new ones (Bodoky et al. 2004, 2006).

\section{M eteorite impact craters on the Earth}

Meteorite impacts on Earth were once regarded as an exotic but geologically insignificant process. During the last decades, however, there has been an increasing realization that they are a major factor in the geologic and biologic history of our planet (French 1998). At present there exists a wide-ranging literature on the subject of the known terrestrial impact craters and of their frequency, formation and geologic consequences; moreover, in the year of 2006 the ESA (European Space Agency) organized an international conference on 
impact cratering in the solar system (8-12 May 2006, Noordwijk, the Netherlands). Thus the geology of impact craters does not need further discussion. On the other hand, in view of the subject of the present study, a brief overview of their geophysical characteristics will be given.

The geophysical signature of terrestrial impact craters was discussed and summarized by Pilkington and Grieve. In their work they took into consideration all known craters of the time (Pilkington and Grieve 1992); the present study will rely primarily upon their data and considerations.

\section{Gravity signature}

Impact craters usually present themselves by negative gravity anomalies. The reason for this is the unconsolidated crater fill and fractured zone around the crater, which exhibit lower density than that of the intact target rocks.

According to Pilkington and Grieve there is a relationship between the amplitude of the gravity anomaly and the diameter of the crater. With craters of small diameter $(<10 \mathrm{~km})$, the probable maximum negative gravity anomaly in $\mathrm{mGal}$ corresponds to the size of the diameter in $\mathrm{km}$ (with, however, a strong scatter), but the gravity effect of large craters never extends beyond $-20 \mathrm{mGal}$.

\section{$M$ agnetic signature}

Due to the complex characteristics of the magnetic field and the magnetic properties of rocks, the relationship of the impact craters to magnetic anomalies is not as simple as in the case of gravity. Pilkington and Grieve claim that in many cases impact craters have no recognizable magnetic effect at all. If they do, then it is usually typical that a previous magnetic anomaly pattern of the target area was disturbed or modified (usually attenuated) in the crater area.

\section{Electrical signature}

Brecciation and fracturing of target rocks can significantly modify their electrical properties, since the conductivity of rock depends strongly upon its water content. Pilkington and Grieve point out that a minor alteration in terms of fracturing (less than 1\%) can result in an order of magnitude or more of change in conductivity. Because of the increased fluid content of the brecciated and fractured zones the impact structures are usually characterized by positive conductivity anomalies. Thus in general electrical methods can be applied to map them. Pilkington and Grieve mention that, at the Siljan and Chalevoix craters, magnetotelluric (MT) surveys indicated conductive zones at greater depth beneath the crater structures (5-20 km at Siljan and $1.5 \mathrm{~km}$ at Charlevoix). At both cases this feature was explained by impact-induced fracturing or faults. 


\section{Seismic signature}

The unconsolidated crater fill and the brecciated and fractured zones of an impact structure present themselves as zones of decreased seismic velocity. The relative change of seismic velocities is larger than the corresponding change in density. According to Pilkington and Grieve a 5\% change in density resulted in a $50 \%$ change in seismic velocities at the Barringer Crater in North America.

If the crater is located at the surface, or if it is buried but the seismic velocities in the target rocks are definitely higher than those in the overburden (i.e. the overburden target rock interface forms a seismic refracting horizon), then the decrease of seismic velocity can be detected and mapped with a seismic refraction survey.

Buried craters can be found by seismic reflection surveys as well. They can be recognized by means of their geometry; if a seismic reflection line crosses a buried crater, then the characteristic morphology of an impact structure will appear in the section.

\section{Geologic evidence}

After summarizing the geophysical signature characteristic for impact structures, it has to be stated that geophysical attributes can only indicate the meteorite-impact origin of a structure, or at least the probability of it, but according to present-day scientific opinion cannot provide final proof. This statement is especially true in the case of buried structures. The meteorite-impact origin of a structure can only be verified by geologic and mineralogical investigations for unique shock-metamorphic features in the rocks involved. Thus, in the case of buried structures, the examination of core samples is of primary importance (French 1998).

Confirmed terrestrial impact craters are collected in databases, which can be found on the World Wide Web (Earth Impact Database).

\section{The geologic setting of the surroundings of M agyarmecske}

Information on the geologic setting of the surroundings of Magyarmecske is provided by laboratory examination of the cores of deep wells in the area, as well as the interpretation of geophysical sections. Consequently, the oldest geologic formation of the region is represented by strongly and intermediately metamorphosed crystalline schist assigned to the Baksa Complex. Lithologically it is made up of micaschist, phyllite, gneiss and marble (Szederkényi 1998). It does not crop out at surface, but is known from boreholes. In the eastern part of the region it comes close to the surface (boreholes Téseny Té-1, Baksa B-2), while at the western margins the depth increases (Okorág $0-2$ ). This unit is of undifferentiated Paleozoic age. It is overlain unconformably by an Upper Carboniferous sequence (Hetényi and Ravaszné Baranyai 1976). At surfaceUpper 
Carboniferous material occurs only as redeposited gravel in the conglomerates of the Miocene Szászvár Formation (Kassai 1973; Chikán 1991; Szakmány and Józsa 1994), where it was first described (Soós and Jámbor 1960). Subsequently the Téseny Sandstone Formation was traversed, or at least penetrated, by deep boreholes (Bogádmindszent Bm-1, Siklósbodony Sb-1, Téseny Té-3, Té-6, Té-7: Baranyai and Jámbor 1963; Fazekas 1969, 1982; Jámbor 1969; Ravaszné Baranyai 1971). The detailed laboratory examinations of the related borehole sequences show that its material originated from the erosion of mountains consisting of similar formations, as well as from Hercynian crystalline rocks, granitoids and volcanic materials (Barabásné Stuhl 1987-88). The eroded material of the mountains accumulated in an intramontane molassic basin. Its grain size ranges from coarse polymict conglomerate to fine pelitic sediments (clay schist, siltstone schist). Occasionally it bears some thin anthracite intercalations (Kassai 1973, 1980, 1983). The conglomerate has a siliceous, sericitic, chloritic, occasionally carbonate matrix, while in the coarser sequences the grains are pressed together without matrix (Varga et al. 2001). Sedimentation was of cyclic character, with an upward-fining trend. The thickness of the small cycles is of the order of $10 \mathrm{~m}$ (20-50 m); washout phenomena can just barely be observed at the beginning of the cycles (Jámbor 1998). Based on the main and trace element contents, the most recent studies provide clues on the denudation area and the sedimentary environment (Varga 2000; Varga et al. 2001). Some experts believe that the sequence penetrated by the two boreholes (Sb-1, Bm-1) represents the younger and the older parts of the same formation, respectively (Jámbor 1998). According to some plant and pollen remains occurring in the sequence, the Téseny Sandstone Formation can be assigned to the Westfalian stage of the Upper Carboniferous (Jámbor 1998; Fülöp 1994). To the SE of the area it is covered by the Lower Permian fluvial Korpád Sandstone Formation (Barabás and Barabásné Stuhl 1998). Views differ whether they are conformable (Fülöp 1994) or in tectonically contact (Barabásné Stuhl 1987-88; Jámbor 1998). To the WNW, Upper Carboniferous formations are overlain unconformably by Pannonian and Miocene (Badenian) deposits. The thickness of N eogene sediments overlying the Téseny Sandstone Formation increases considerably to the west. Upsection Upper Pannonian formations appear in the Neogene sequence as follows: Kálla Gravel Fm., Somló Fm., Újfalu Sandstone Fm., and Zagyva Fm. Close to the surface the Upper Pannonian deposits are covered by diverse Quaternary sediments. Their lowermost part is commonly represented by the Tengelic Red Clay Formation (Chikán 1991). The section is terminated by loess as well as fluvial and deluvial Pleistocene deposits directly overlying the Upper Pannonian sequence or the Tengelic Red Clay Formation.

If the geology in the close vicinity of the Magyarmecske telluric CA is summarized from the point of view of geophysics, then a rather simple three layer model can be used. The deepest layer is the old crystalline basement, which is overlain by thick Carboniferous sedimentary formations making up the second 
layer, while the uppermost (third) layer is formed by the Neogene sediments covering the area.

\section{Geophysical investigation in and around the area of the M agyarmecske telluric CA}

Since the publication of the telluric map of West Hungary, only a few gravity and magnetic points have been measured in the Magyarmecske area; thus the reinterpretation had to be restricted to data available earlier as well.

\section{Electrical data: telluric data}

The starting-point of the reinterpretation was provided by the electrical data. All other investigations were connected to the telluric conductivity map of the area, which had previously been discussed in detail (Nemesi et al. 2000) (Fig. 1).

Figure 3 presents the telluric anomaly map in a more detailed form; it also indicates the locations of boreholes and seismic reflection sections. In Figs 1 and 3 it can be seen that while conductivity usually lies between 50 and $300 \mathrm{~S}$ (siemens) over the area, at Magyarmecske and Magyartelek it increases by more than an order of magnitude, and between the two villages its peak goes well beyond $2000 \mathrm{~S}$. The shape of the anomaly resembles an ellipse with a W-Edirected, 7-8km-long major axis and a N-S directed, 5-6km-long minor one. The anomaly is slightly asymmetrical; maximum conductivity values are shifted westward.

\section{Electromagnetic data: magnetotelluric (M T) data}

MT measurements were carried out over the area of the telluric CA and its neighborhood as well. MT sounding curves processed by 1-D inversion show the expected characteristics outside of the area of the anomaly: young Neogene sediments show low resistivity values (10 to $20 \Omega \mathrm{m}$ ), the underlying Carboniferous formations higher ones (60 to $80 \Omega \mathrm{m}$ ) and the Pal eozoic crystalline basement appears with very high resistivity $(>400 \Omega \mathrm{m})$, forming the "highresistivity geoelectric basement" (Varga 1977). In the area of the telluric CA, on the other hand, the character of the curves is different: immediately beneath the young sediments the soundings indicate a formation of extremely low resistivity $(<1 \Omega \mathrm{m})$ (Fig. 2). Soundings carried out later, however, show that below that the resistivity values correspond to those of the young sediments, but with a rather large scatter (Draskovits et al. 1994). In the area of the anomaly the "electrical high-resistivity basement" is located deeper: the difference compared to its depth outside the area can be on the order of several $100 \mathrm{~m}$ (Nemesi et al. 2000). 

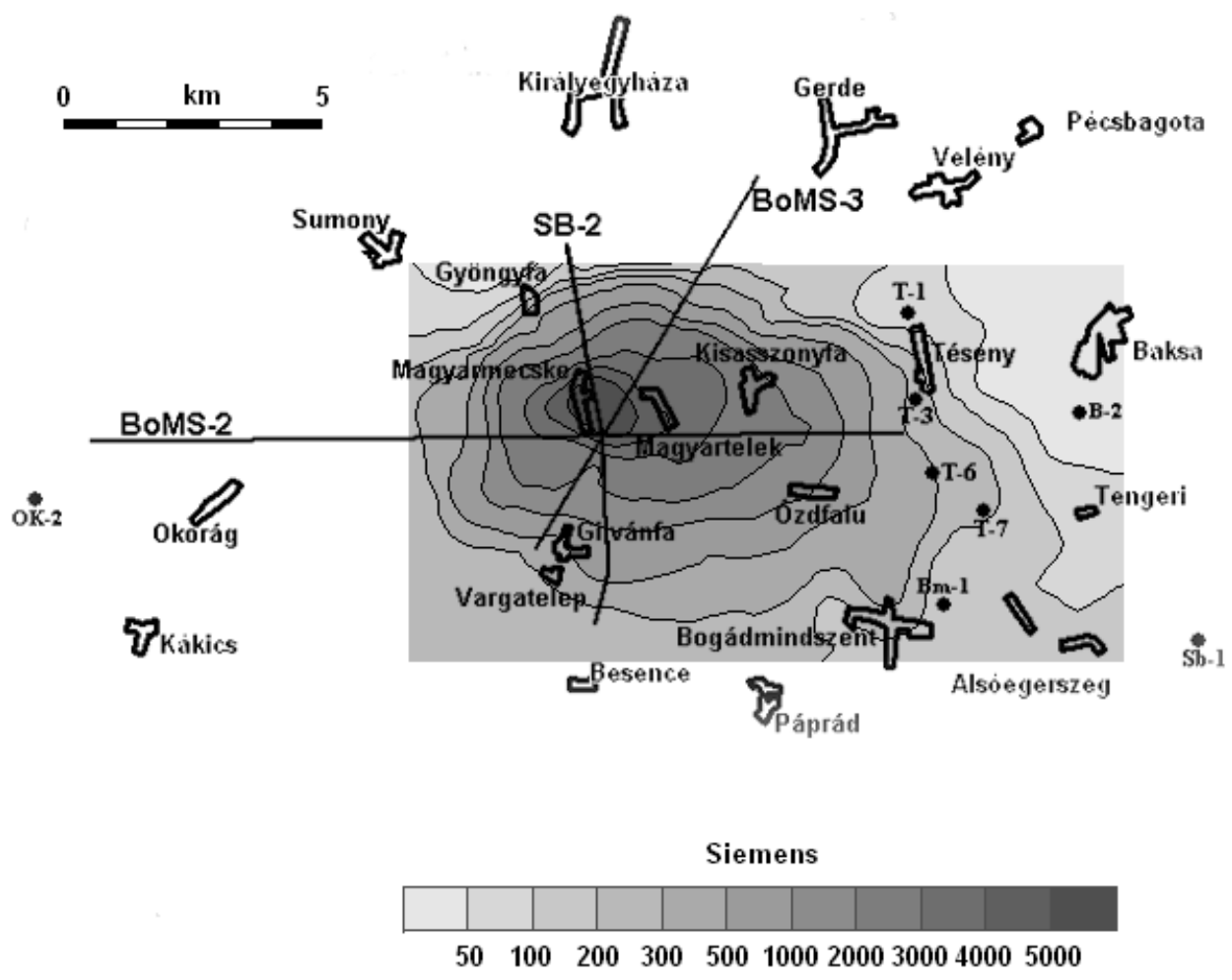

Fig. 3

Detailed map of the telluric conductivity anomaly (CA) at Magyarmecske, with the location of the seismic reflection lines and the boreholes

Electrical data: vertical electrical sounding (VES) data

Among the vertical electrical soundings measured within the scope of a regional hydrogeologic survey in Belsõ Somogy (SW Hungary) from 1990 to 1993, a considerable number were emplaced in the area of the Magyarmecske telluric CA. The survey was carried out using large electrode separations, so that their depth of penetration was sufficient to investigate the depth range in question. The data can be found in the National Geoelectric Database (in the Eötvös Loránd Geophysical Institute), comprising data from over 40,000 VES measurements. Information in the database can be processed automatically by 1-D Marqardt-type inversion; and all 1-D inversions in the area taken together provide a good 3D view of the resistivity relationships of underground structures. Eighty-five VESs were chosen from the studied area, of a surface of approximately $350 \mathrm{~km}^{2}$; a set of maps representing the DC resistivity relations of the Magyarmecske telluric CA was compiled from their inverted data. The maps 
depict horizontal slices of the 3D interval resistivity distribution in the depths of $200 \mathrm{~m}, 400 \mathrm{~m}, 800 \mathrm{~m}$ and $1600 \mathrm{~m}$ (Figs 4, 5, 6 and 7).

It can be seen that the slices at lesser depth do not indicate any resistivity anomaly; here the resistivity values of young sediments predominate with 20-30 $\Omega \mathrm{m}$ (Fig. 4). In the northeastern part of the area increased values appear, due to uplifted older formations. One step deeper on the next slice (Fig. 5), the bulk of high-resistivity formations occupy almost one-third of the area to the east, corresponding to the depth and dip relations known here. However, between the villages of Magyarmecske and Magyartelek, a small circular anomaly appears. Descending another step, on the slice of Fig. 6 this anomaly appears unambiguously in a roughly circular form with a diameter of $4-5 \mathrm{~km}$. Its very low resistivity $(<10 \Omega \mathrm{m})$ differs significantly from that of its surroundings. Again one

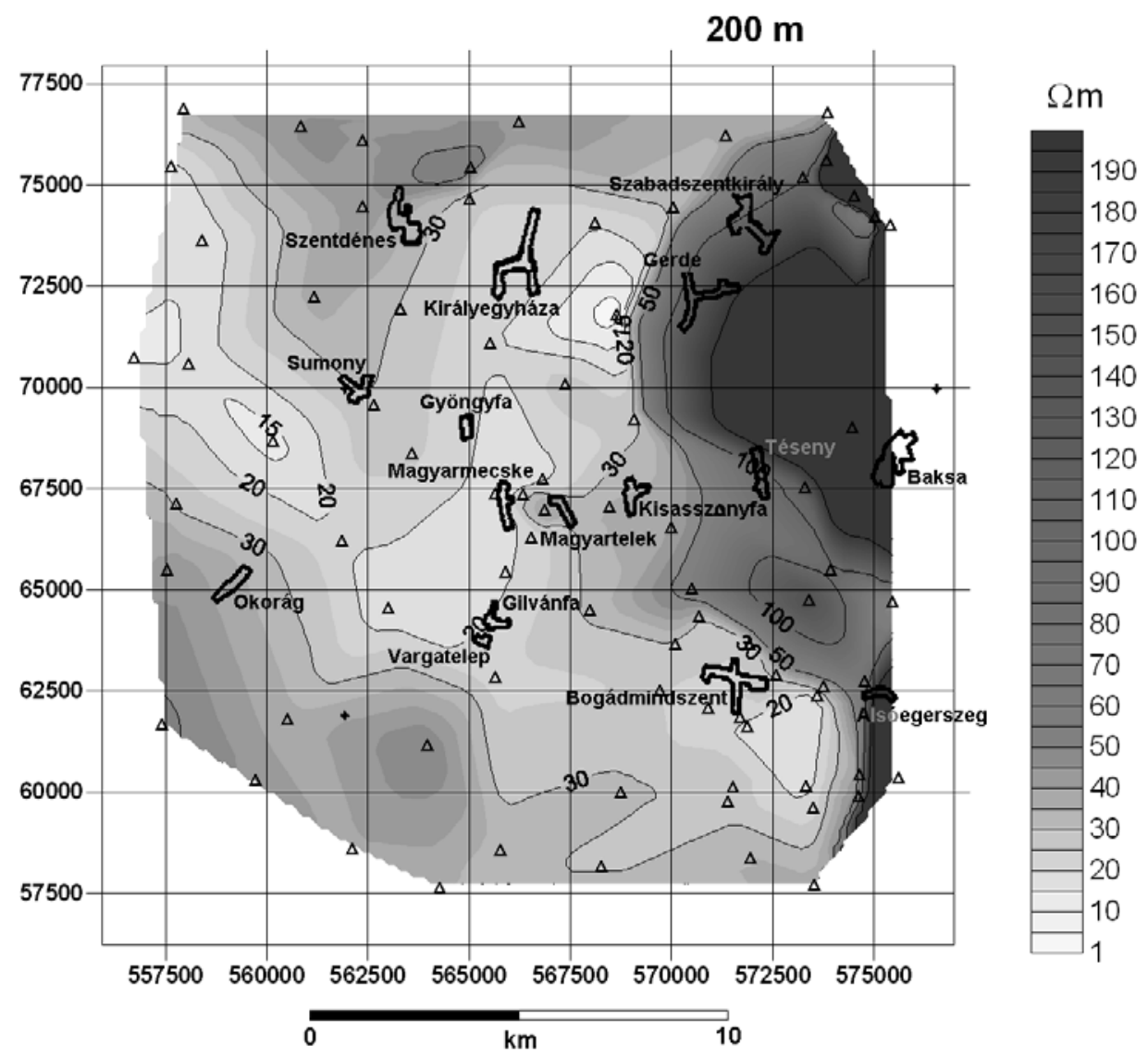

Fig. 4

Locations of the vertical electric sounding (VES) points and the interval resistivity distribution at a depth of $200 \mathrm{~m}$. At this depth the western part of the study area shows 20-30 $\Omega \mathrm{m}$ resistivity, typical for loose sediment, while to the northeast the effect of the high resistivity formations can be seen 


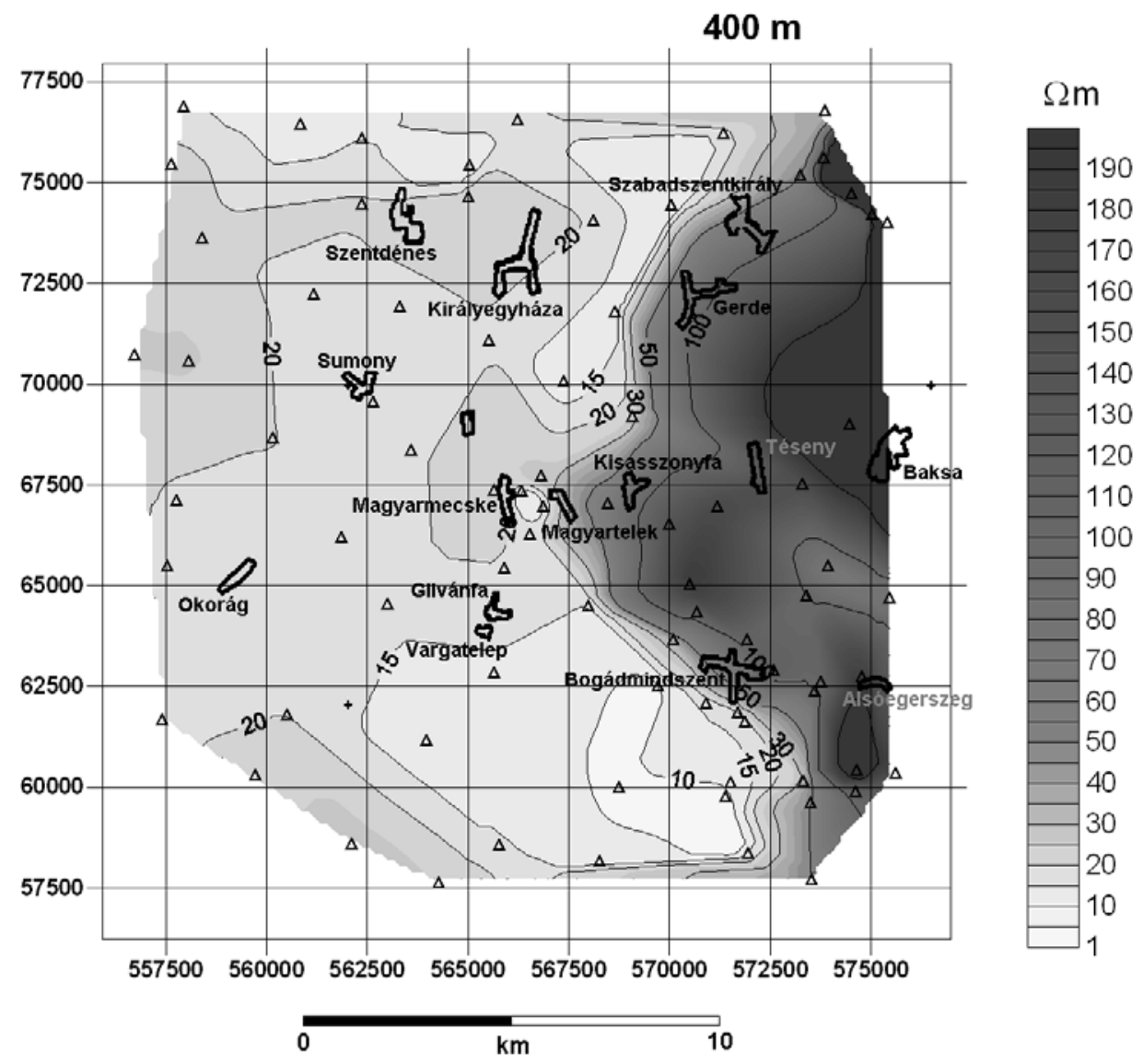

Fig. 5

Locations of the VES points and the interval resistivity distribution at a depth of $400 \mathrm{~m}$. At this depth the western part of the study area shows the 20-30 $\Omega$ m resistivity typical for uncompacted sediment, while to the east the high-resistivity formations occupy about one-third of the horizontal slice

step deeper, on the last slice (Fig. 7) its effect is still noticeable, although the circular symmetry disappears and the anomaly appears in the form of a SWdirected low-resistivity zone.

Gravity data

The station density over the telluric CA and its immediate neighborhood is on average 1.65 station $/ \mathrm{km}^{2}$, which is rather low in view of the size of the area. Furthermore the distribution of the stations is fairly uneven because they are located along roads. 


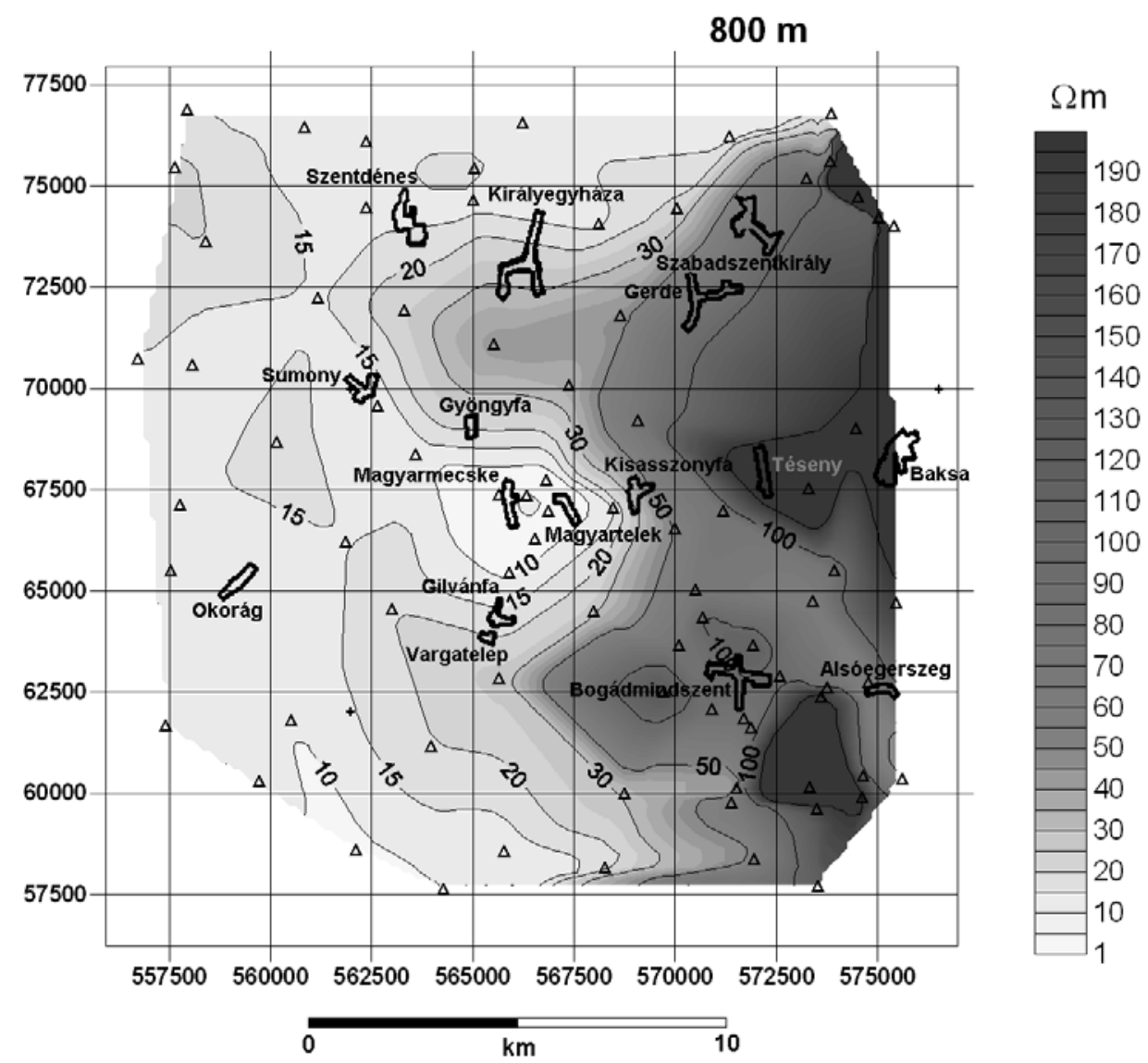

Fig. 6

Locations of the VES points and the interval resistivity distribution at a depth of $800 \mathrm{~m}$. At this depth the high-resistivity formations occupy a large part of the horizontal slice. At Magyarmecske a circular low-resistivity anomaly appears in the high-resistivity block. In the center of the anomaly the resistivity is only $2-5 \Omega \mathrm{m}$

Figure 8 presents the Bouguer anomaly map of the area. As can be seen it is dominated by a saddle-like regional trend, and superimposed upon it, a circular gravity minimum is located at Magyarmecske. It was attempted to separate the effect of the assumed local structure from the regional trend by computing residual anomaly maps. For this Gauss-type low-pass filters were used, with cutoff wavelengths of 2 to $1.3 \mathrm{~km}$. Two of the residual gravity anomaly maps are presented in Figs 9 and 10. These maps reveal step by step a circular, almost closed, annular negative gravity residual anomaly over the area of the Magyarmecske telluric CA, of a diameter of $7-8 \mathrm{~km}$. In the center of this negative anomaly is a positive one, shifted slightly eastward, of a diameter of about $2 \mathrm{~km}$. 


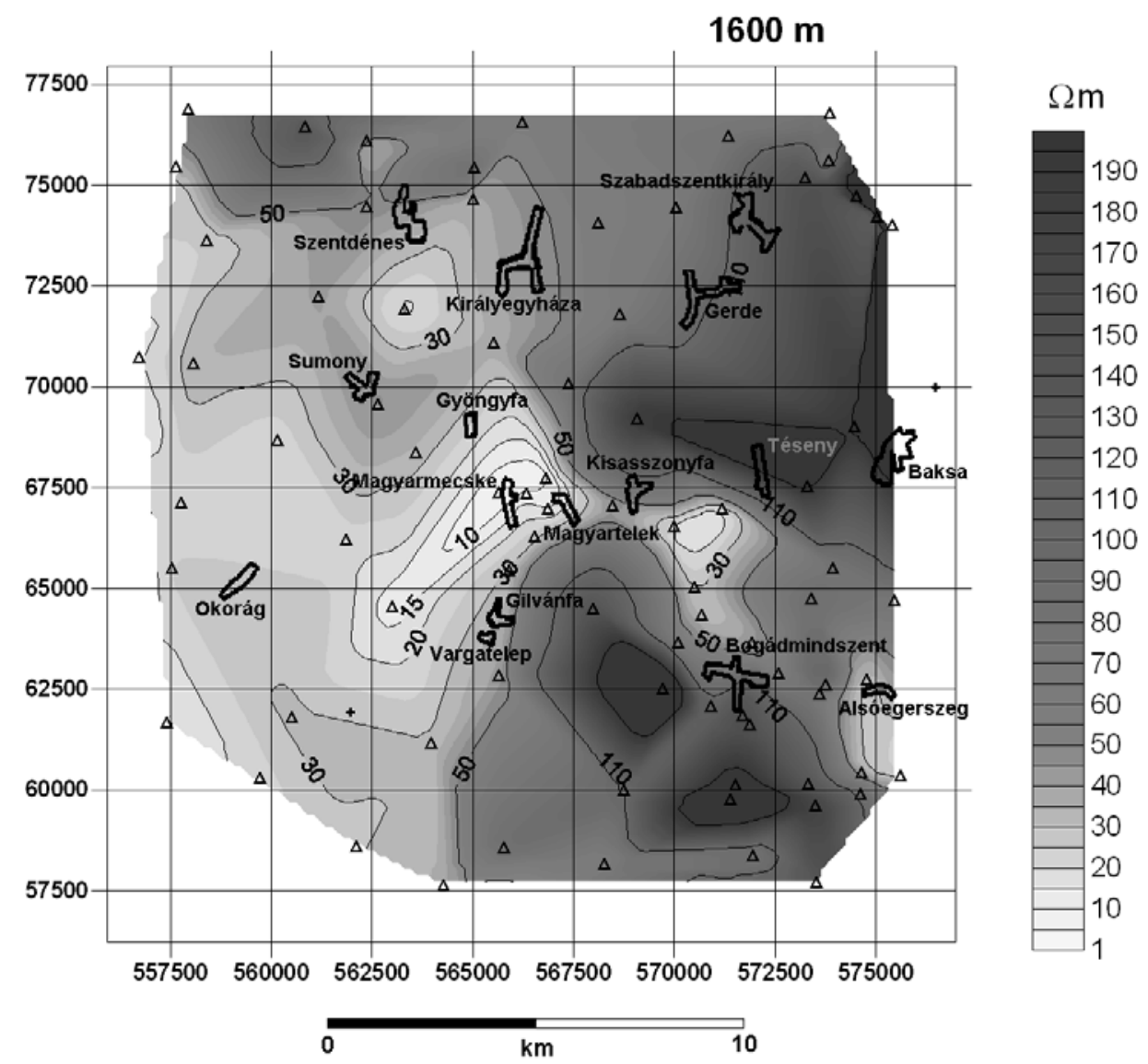

Fig. 7

Locations of the VES points and the interval resistivity distribution below a depth of $1023 \mathrm{~m}$. Here the low-resistivity anomaly loses its circular form, but a SW-directed low-resistivity strip appears

The latter can be seen increasingly well as the cut-off wavelength is gradually lowered during filtering. 
Is the M agyarmecske telluric conductivity anomaly a buried impact structure? 211
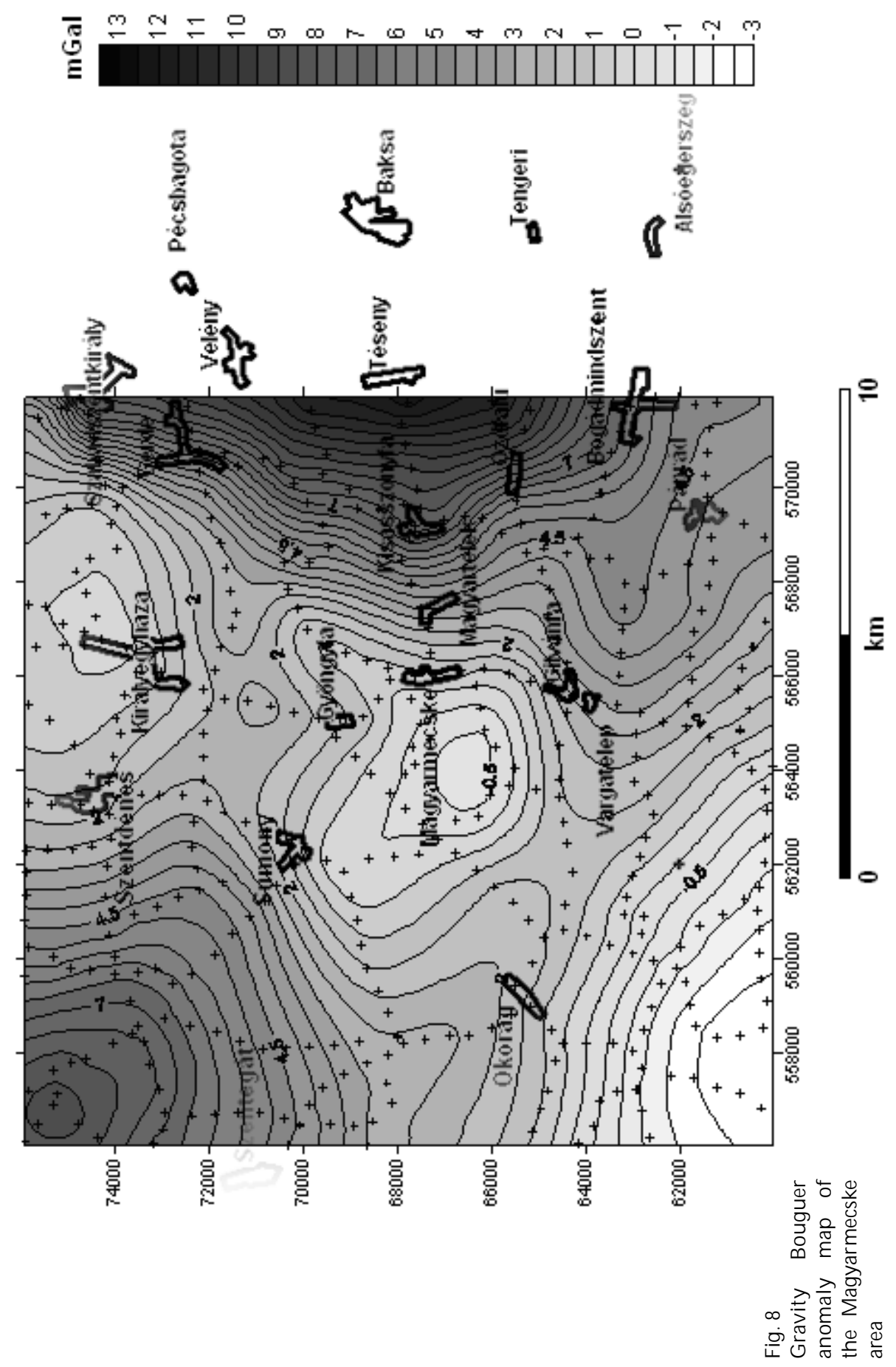


\section{T. Bodoky et al.}

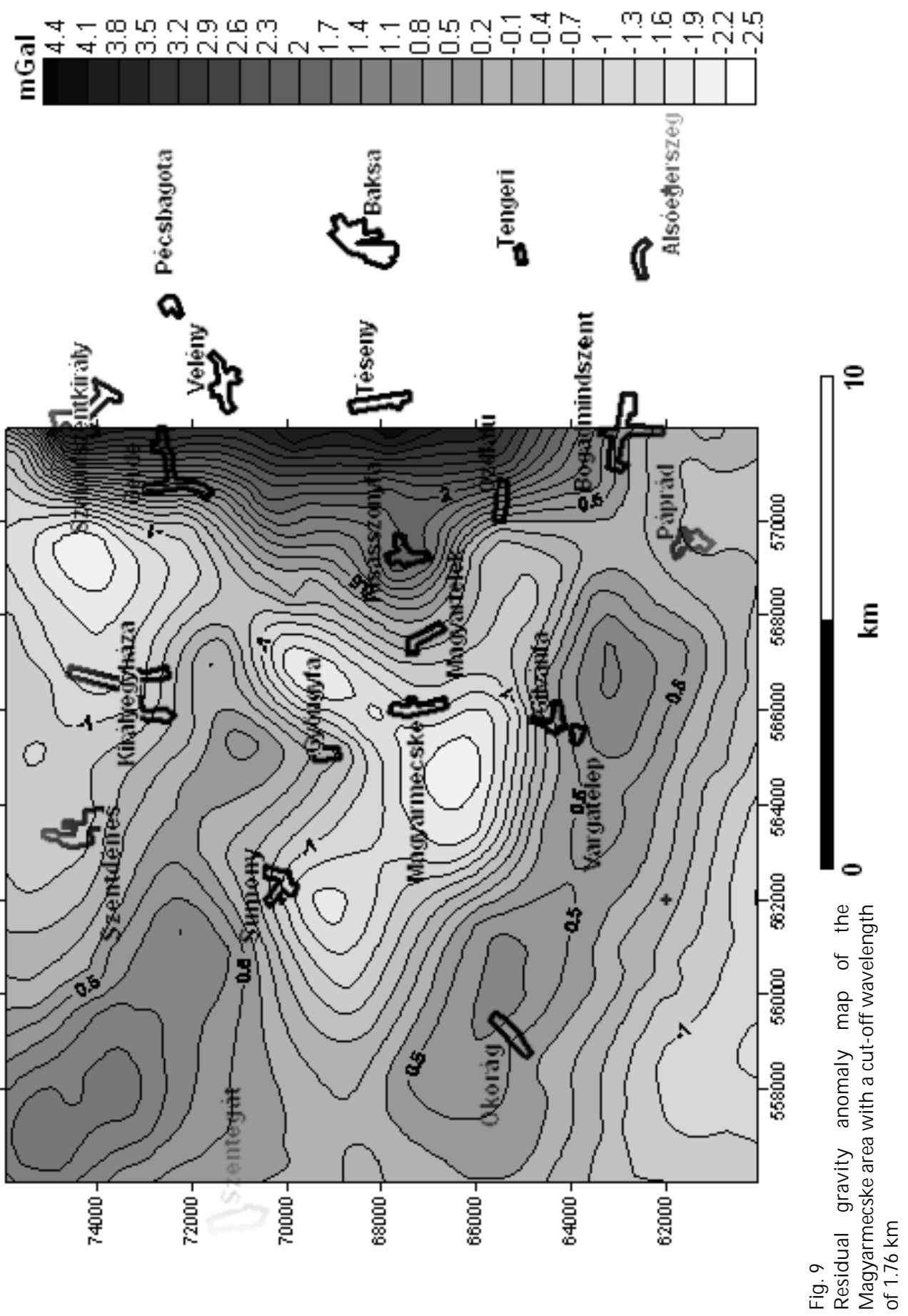

Central European Geology 50, 2007 


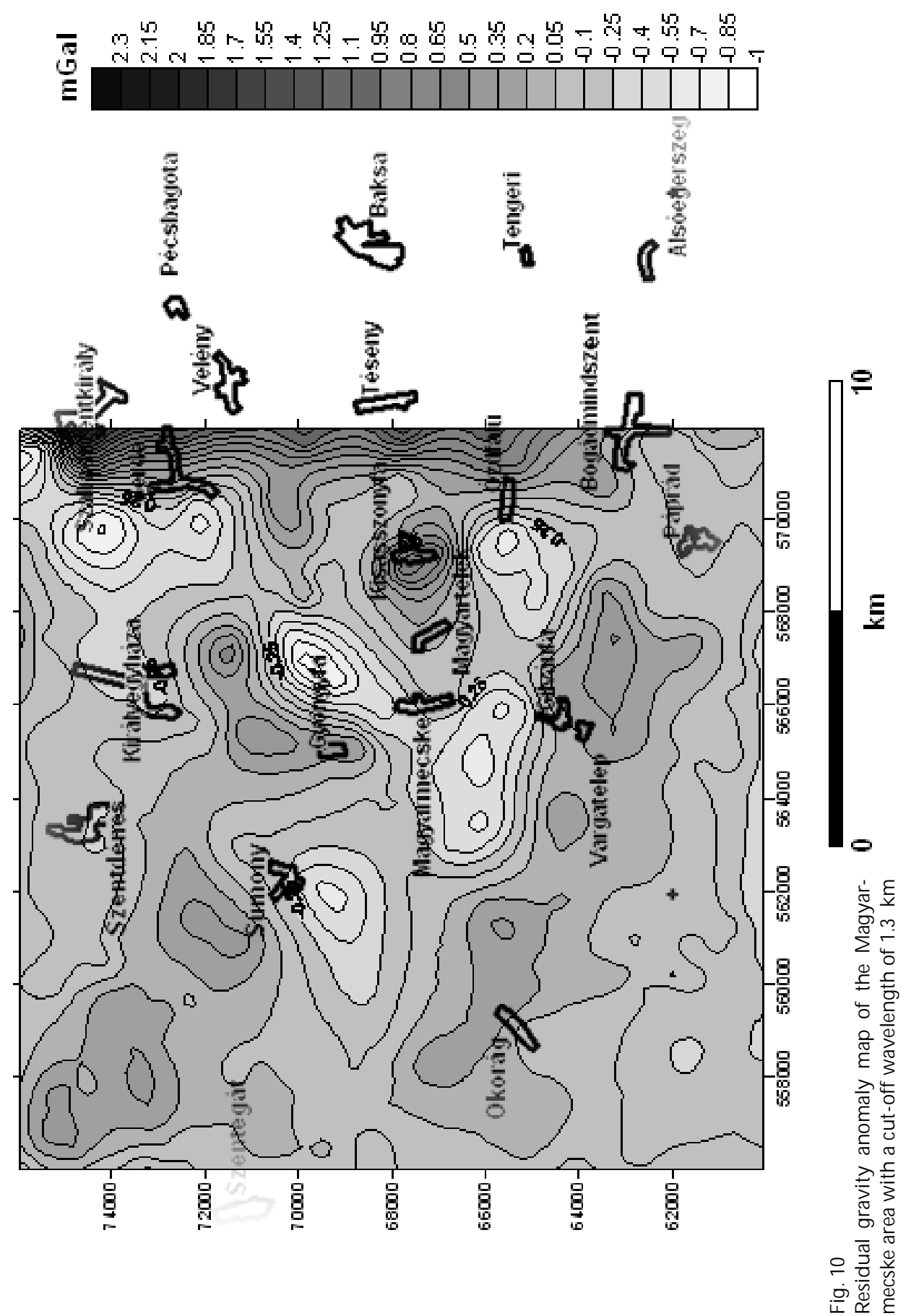




\section{T. Bodoky et al.}

M agnetic data

The magnetic field of the study area is rather characterless, and the density of magnetic measurements is relatively low; thus, for the reinterpretation of geophysical data of the study area, magnetic data were not used.

\section{Seismic refraction data}

The studied zone is part of the area of a large-scale seismic refraction survey carried out by OKGT (Hungarian National Oil and Gas Co.) in 1959-1960. As one of the results, a velocity map of the seismic refraction basement was included in Survey Report No. 63, compiled by the Seismic Prospecting Company of OKGT in 1960. As has been pointed out by Nemesi et al. (2000) it is remarkable that seismic refraction velocities of the area of the Magyarmecske telluric CA showed a $10-20 \%$ decrease compared to those of surrounding locations (Fig. 11).

When discussing seismic refraction data it is necessary to point out the difference between depths of geoelectric and seismic basements. According to

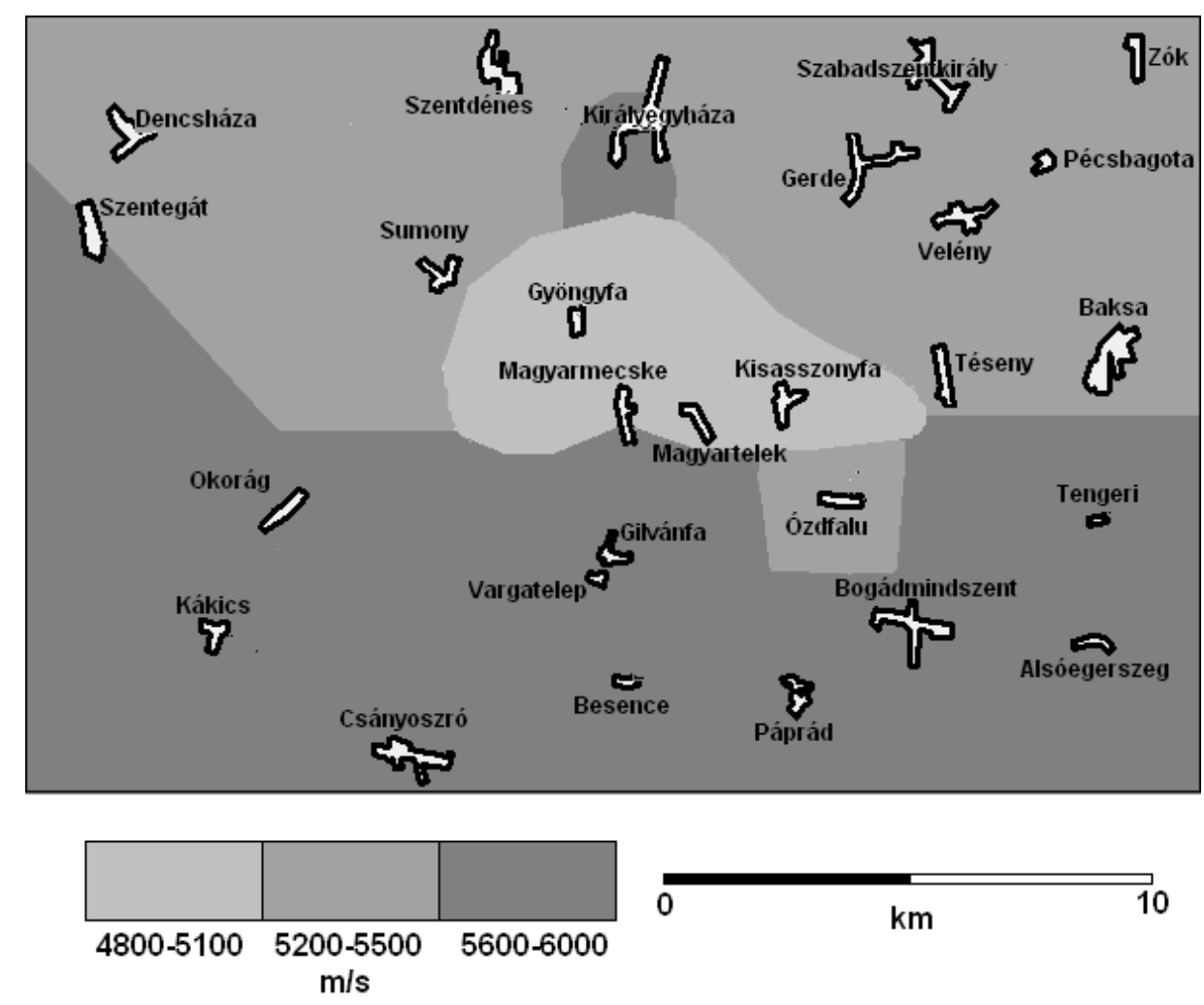

Fig. 11

Seismic refraction velocity distribution of the seismic "high-velocity basement" 
Varga the reason for this is to be found in the nature of the Carboniferous formations. Due to their rather high seismic velocities, the NeogeneCarboniferous interface appears as a high-velocity seismic refracting basement; at the same time, due to its low resistivity, the high-resistivity geoelectric basement is linked to the interface between the Carboniferous formations and the Paleozoic crystalline units. Thus the difference of the different basements is an indication of the thickness of the Carboniferous sequence (Varga 1977; N emesi et al. 2000).

\section{Seismic reflection data}

In the very beginning of the seventies of the last century, OKGT also carried out seismic reflection measurements over the study area. These measurements were recorded with analog magnetic instruments and today the results are only available as paper sections. The careful examination of only two sections, BoMS2 and BoMS-3, proved to be useful for the study (Fig. 3). The two seismic lines were shot in 1971 using a sixfold split spread system and with 30-m intervals between geophone groups of five each. Processing was carried out using a Texas Instruments TIOPS system, following a sequence usual at the time, i.e. static and NMO corrections, stacking, frequency filtering, and deconvolution were performed on the data.

Line BomS-2 extended from Okorág as far as Téseny, in a W-E direction, crossing the Magyarmecske telluric CA almost at its center. At the western end of the section the top of the Carboniferous formations is located at a depth of over $1.5 \mathrm{~km}$, while at its eastern one (Shotpoint (SP) 13.8) the depth is only slightly more than $100 \mathrm{~m}$. The western side of the assumed impact structure can be well seen on the section. The western rim appears at SP 5.9 at the strongly dipping top of the Carboniferous formations; from here the line crosses the western low of the ring (about $4 \mathrm{~km}$ long), then the central uplift from SP 10 to 11.8; beyond SP 11.8 the eastern side of the ring and the eastern rim should appear, but they were probably removed by erosion (Fig. 12).

Line BoMS-3 begins at Gilvánfa, within the telluric CA, and crosses the central uplift, which it reaches at SP 15.5, in a north-northeasterly direction (Fig. 3). In the northern part of the section the presence of structural elements is uncertain, from which it is reasonable to infer strong erosional activity. The northern rim is indicated by a change of character of the seismic imaging of the section rather than by the shape of the reflections. At this point multiples abruptly become much stronger (Fig. 13). The most characteristic event of the section is a late movement at SP 13.5, which is also found in Line BoMS-2. The latter section crosses it at a low angle, approximately at SP 4.5.

In 1992 the Eötvös Loránd Geophysical Institute recorded a digital seismic reflection section (Line SB-2), which crossed the Magyarmecske telluric CA in a $\mathrm{N}-\mathrm{S}$ direction (reversed to BoMS-3). On the section the typical cross-section of a complex impact crater between SP 50 and 650 can easily be recognized, at the top 
216 T. Bodoky et al.

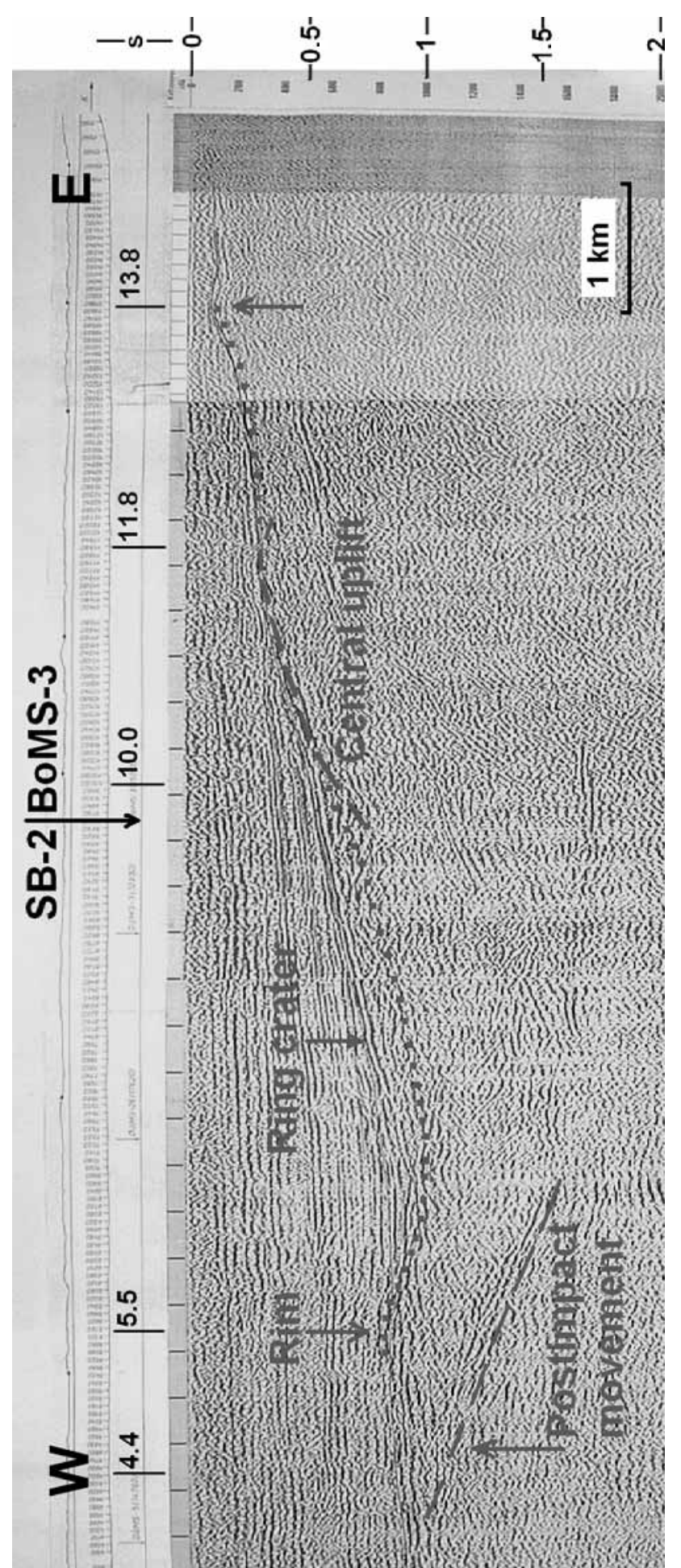

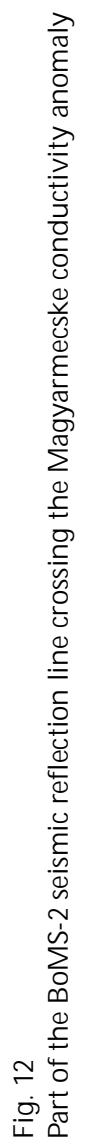


Is the M agyarmecske telluric conductivity anomaly a buried impact structure? 217

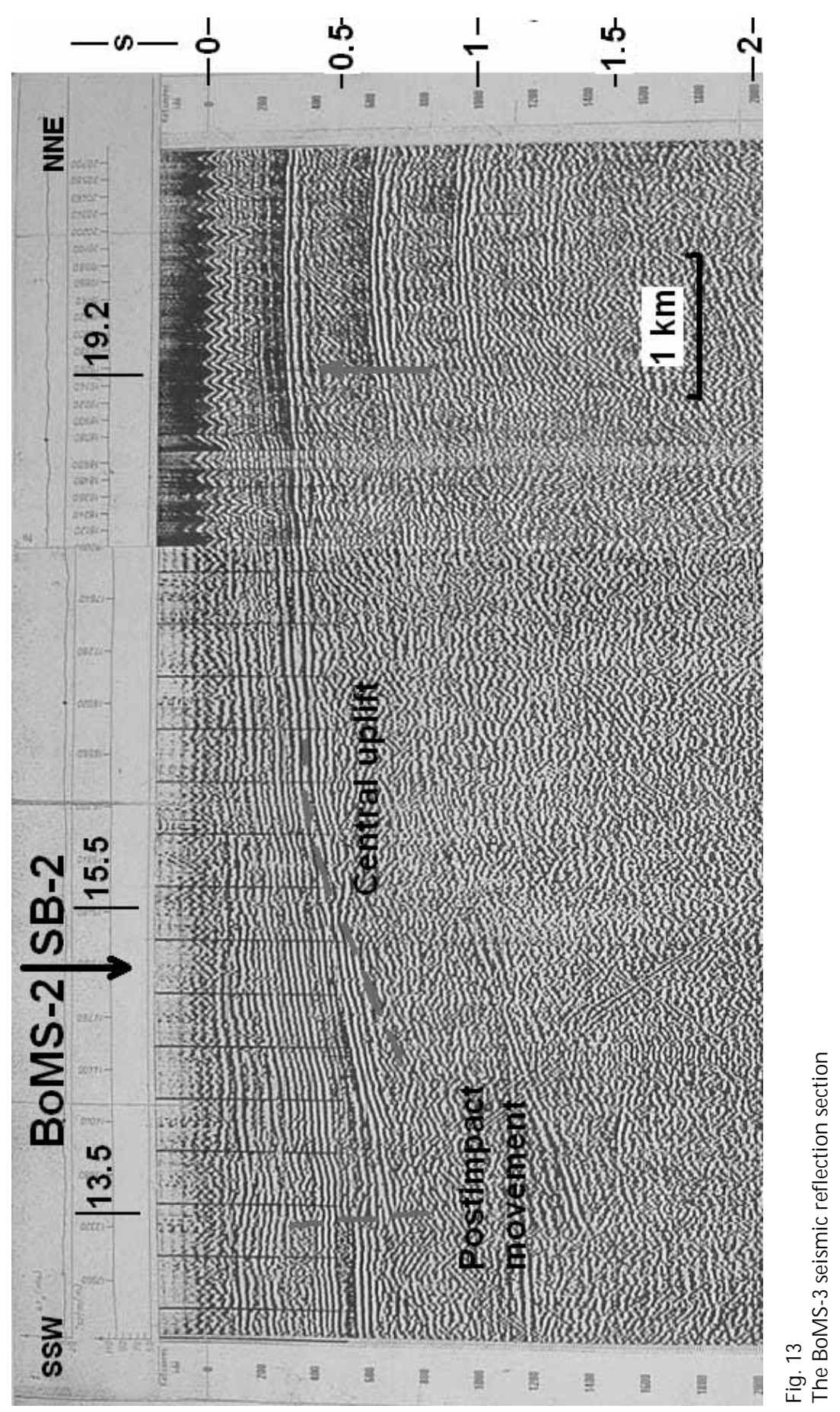

Central European Geology 50, 2007 
of the Carboniferous formations, within the time interval of 500 to $1000 \mathrm{~ms}$ (Fig. 14). If the effect of the young movement mentioned above is removed then the crater's shape is even more obvious.

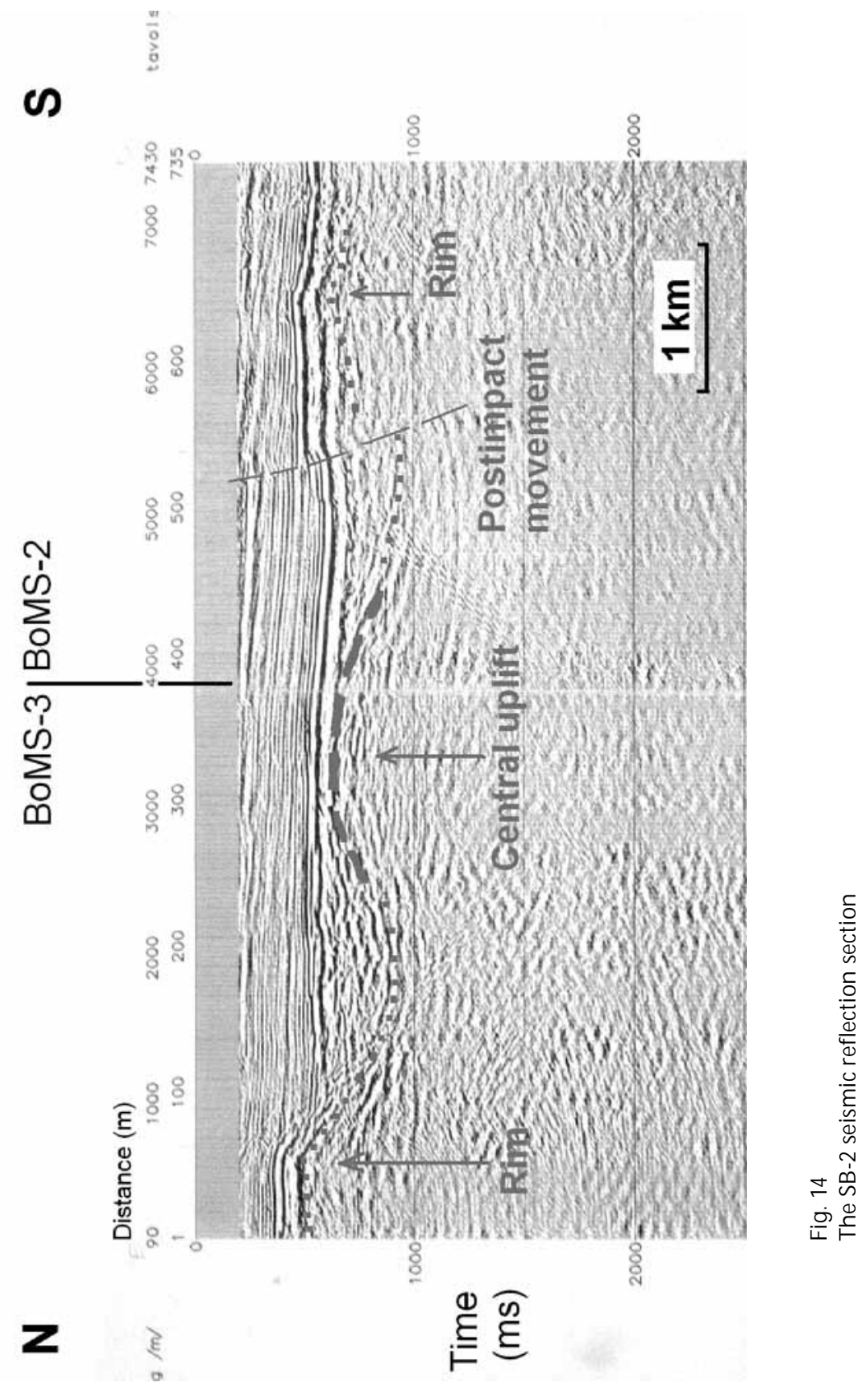




\section{Conclusions}

Geologic and geophysical data of the study area confirm the earlier interpretation, which attributes the Magyarmecske telluric CA to graphitized Carboniferous coal beds (Ádám 1980); there is no evidence pointing to any other possibility. However, if this is accepted, then the manner in which graphitization occurred, and the reason for its only occurring at this location, require explanation.

In the Earth's crust, high temperatures and, in particular, high pressures are required to form graphite (Koch 1997), which has a substantially higher density than other forms of coal (Kwiecinska 2006). However, the Carboniferous sequence shows no evidence of metamorphism, i.e. of high temperature and high pressure, and the limited area of graphitization also contradicts a metamorphic origin.

Wilks et al. (1993) point out that the driving force of graphitization is strain energy and shear strain. Extreme shear strain may take place along tectonic lines, especially where they intersect each other. Majoros (2000) has drawn attention to the tectonic features of the region. The study area is located along a large strikeslip fault running in a SW-NE direction and forming the northwestern boundary of the telluric CA. Geophysical data (Figs 5 and 9) also indicate intersecting structural lines. Thus the telluric CA could be explained by extremely high shear strain caused by tectonic movements along lines crossing each other. The weakness of this solution, however, is that sedimentary sequences can usually not accumulate extremely high strain rates, and both the above-mentioned resistivity and residual gravity anomaly maps indicate the known and assumed tectonic lines as uncompacted (low resistivity and low deensity) zones.

Based on the described geophysical signature of the studied area the conclusion was reached that the geologic-geophysical phenomenon known in Hungarian literature as the Magyarmecske telluric conductivity anomaly can be better explained as an impact structure. It might have originated through a cosmic body impacting the surface of the Carboniferous formations. As a consequence of the impact a single-ring complex crater was formed, with an outer diameter of 6-8 km.

Following the impact the Carboniferous formations were tilted westward (alternatively, the impact occurred at an angle). The western part of the crater was inundated (unless the impact occurred at a seashore), and water covered it up to the central uplift. Sedimentation below sea level began, with simultaneous erosion and sediment removal along its eastern and northeastern zones: here the crater itself has been for the most part removed, but the brecciated and fractured zones below and around the crater remained. Subsequently the entire area dropped below sea level and was covered by young sediments, while late tectonic movements deformed the original circular symmetry (Fig. 15).

As far as the simplified geologic model is concerned, for the time of impact it consists of two layers only, the crystalline basement and the overlaying 


\section{T. Bodoky et al.}

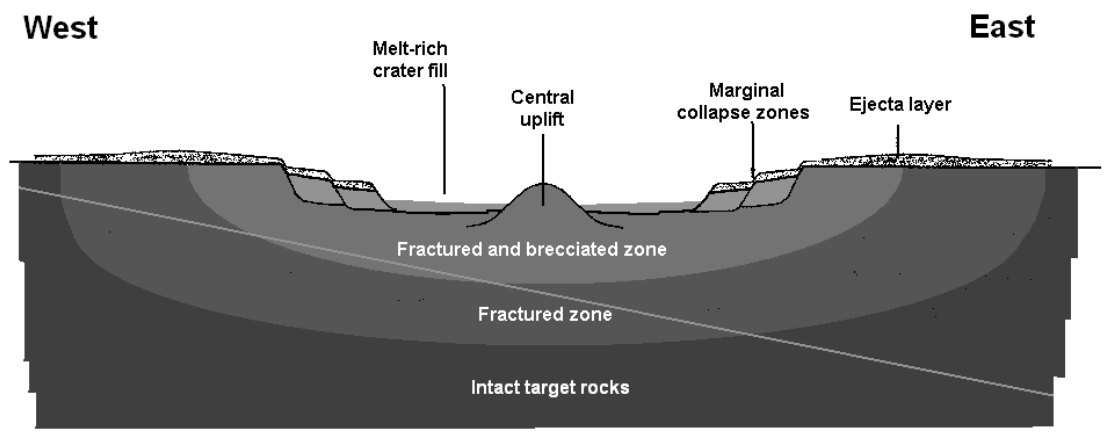

A

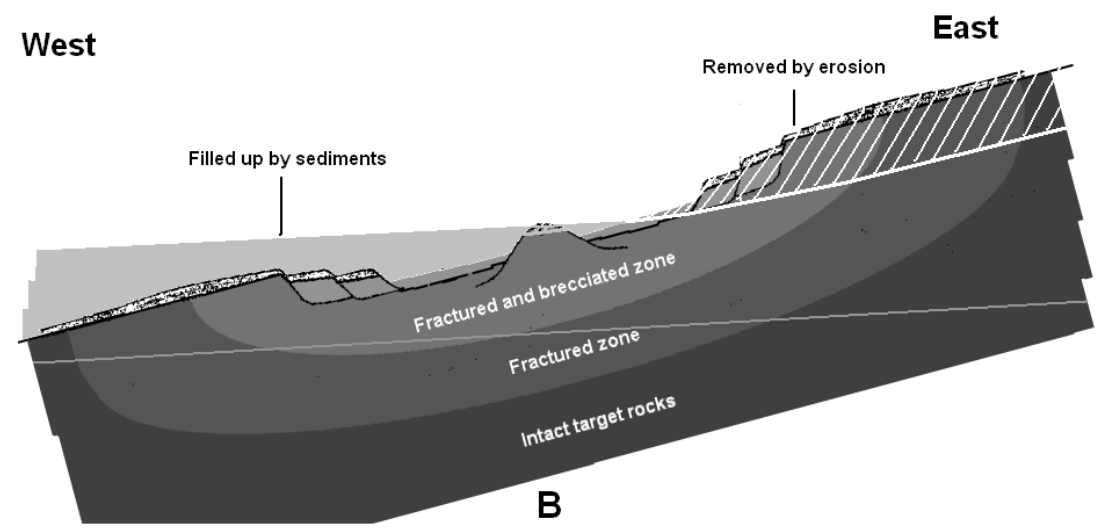

West

East

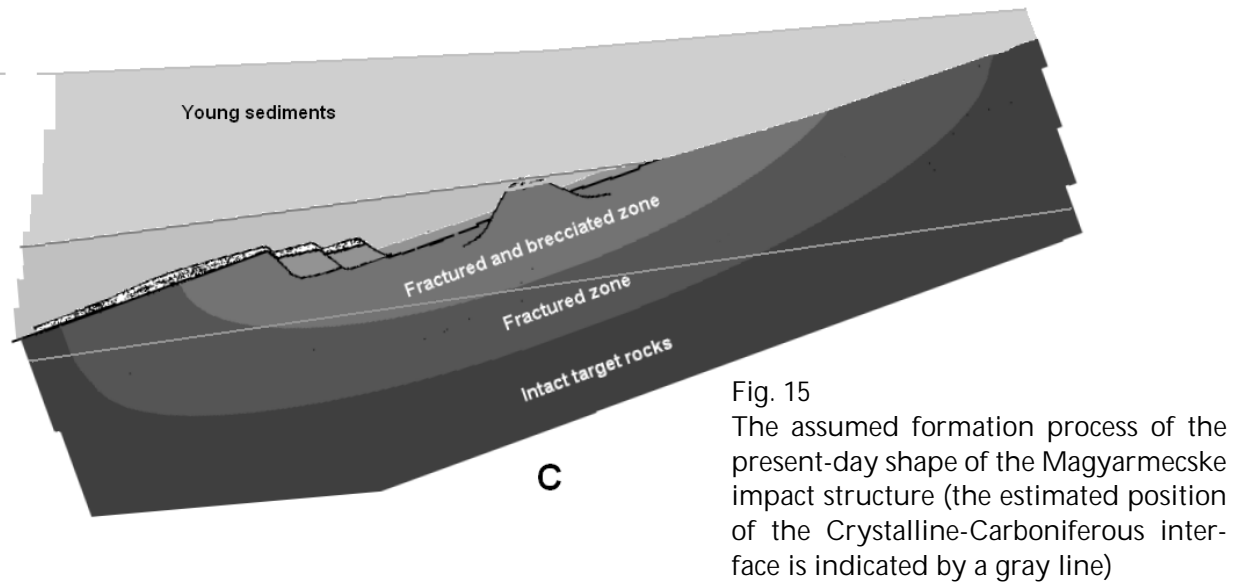

Central European Geology 50, 2007 
Carboniferous sediments. The position of their interface, estimated from the data of $\mathrm{Nemesi}$ et al. (2000), is indicated in Fig. 15 by a gray line.

The projectile hit the surface of the Carboniferous sequence and the impact's extreme heat and extreme pressure graphitized the coal beds within it. Thus graphite is connected only to the impact structure, or perhaps only to its inner zones, i.e. to the crater fill and to the fractured and brecciated zone. It is assumed that the telluric CA is bound to the latter, while the gravity anomaly primarily indicates the surviving segment of the ring trough. This explains the lack of exact overlapping between the two phenomena. The southwesternmost and southernmost part of the crater was uplifted by a late movement, leading to distortion of the shapes of both anomalies.

The impact theory is also supported by the decrease of refraction velocities on the telluric CA. The seismic refraction velocities decrease here but still remain considerably higher that those in young sediments; they show the top of the structure as the seismic "high-velocity basement".

The change in conductivity due to fracturing is much more dramatic; therefore the non-graphitized part of the fractured zone presents itself as an unconsolidated sedimentary formation. There is probably no funnel-like depression at the Carboniferous-crystalline interface, but the fractured zone does penetrate the crystalline rocks; the electrical "high-resistivity basement" indicates its base.

It is concluded that, in order to explain the origin of the Magyarmecsketelluric CA, the most complete answer can be obtained with the impact theory; however, without further geologic and mineralogical evidence, the anomaly itself should only be classified as a "possible impact structure" (http://omzg.sscc.ru/impact/ english.html). According to international criteria the final answer will only be obtained by investigating available core samples (French 1998).

\section{Acknowledgements}

The authors thank Mária Hámorné Vidó for valuable help in coal geology, as well as Antal Ádám and György Majoros for helpful comments on the manuscript.

The authors express their thanks to the Eötvös Loránd Geophysical Institute of Hungary for supporting the research.

\section{R eferences}

Ádám, A. 1980: The change of electrical structure between an orogenic and an ancient tectonic area. - J. Geomag. Geoelectr., 32, pp. 1-46.

Ádám, A., Z. Nagy, L. Nemesi, G. Varga 1990: Crustal Conductivity Anomalies in the Pannonian Basin. - Acta Geod. Geoph, Mont. Hung., 25, pp. 279-290.

Barabás, A., Á. Barabásné Stuhl 1998: A Mecsek és környezete perm képzõdményeinek rétegtana (Stratigraphic geology of the Permian formations in the Mecsek and its surroundings). - In: Magyarország geológiai képzõdményeinek rétegtana - MÁFI-MOL, Budapest, pp. 187-215. 
Barabásné Stuhl, A. 1988: A Dél-Baranyai dombság és a Villányi-hegység permi képzõdményeinek kutatásáról készített összefoglaló jelentés III. fejezete a perm fekûképzõdményeirõl (General report on study of the Permian formations of South-Baranya and Villány hills, Chapter 3 Underlying formations) - Pécs, MÉV Archives, Manuscript, pp. 54-81.

Baranyai, I., Á. Jámbor 1963: Komplex geofizikai kutatások és geológiai vizsgálatok eredményeinek felhasználása a DK-Dunántúl területén az alaphegység kutatásában (Application of results of complex geophysical exploration and geologic investigations to study the basement in SE Transdanubia). - Magyar Geofizika 3/3-4, pp. 165-176.

Bodoky, T. 2004: Becsapódási kráterek a Földön (Terrestrial impact craters) - Magyar Geofizika, 45, pp. 51-55.

Bodoky, T., M. Kis, I. Kummer, Gy. Don 2006: The telluric conductivity anomaly at Magyarmecske: is it a buried impact crater? - in 40th ESLAB Proceedings CD - First International Conference on Impact Cratering in the Solar System, Noordwijk.

Bodoky, T., I. Kummer, K. Kloska, T. Fancsik, E. Hegedûs 2004: A magyarmecskei tellurikus vezetõképesség anomália: eltemetett meteorit kráter? (The Magyarmecske telluric conductivity anomaly: is it a buried impact crater?). - Magyar Geofizika, 45, pp. 96-101.

Chikán, G. 1991: A Nyugat-Mecsek kainozoós képzõdményei (Cenozoic formations of the Western Mecsek). - MÁFI Annual Report, 1972, pp. 10-74.

Draskovits, P., I. Fejes, A. Milánkovich, I. Rákóczy 1994: Belsõ-Somogy és Baranya regionális geofizikai elõkutatása, jelentés az 1992-ben végzett munkákról (Geophysical reconnaissance survey of Inner-Somogy and Baranya region, Activity report 1992). - Report of Eötvös Loránd Geophysical Institute of Hungary, Manuscript, ELGI Archives, Budapest, pp. 21-22.

Fazekas, V. 1969: A Siklósbodony 1. sz. mélyfúrás maganyagának ásvány-kõzettani vizsgálata (Mineralogical-petrographic study of the cores of borehole Siklósbodony 1). - Pécs MÉV Archives, Manuscript, $201 \mathrm{p}$

Fazekas, V. 1982: A Bogádmindszent 1. sz. mélyfúrással harántolt felsõ-karbon rétegsor rövid ásvány-kõzettani jellemzése (Brief mineralogical-petrographic description of the UpperCarboniferous column traversed by borehole Bogádminszent 1). - Pécs MÉV Archives, Manuscript, $8 \mathrm{p}$.

French, B.M. 1998: Traces of catastrophe: a handbook of shock-metamorphic effects in terrestrial meteorite impact structures - LPI Contribution No. 945, Lunar and Planetary Institute, Houston.

Fülöp, J. 1994: Tésenyi Homokkõ Formáció (Téseny sandstone formation). - In: Magyarország geológiája. Paleozoikum II. - Akadémiai Kiadó, Budapest, pp. 322-332.

Hetényi, R., L. Ravaszné Baranyai 1976: A baranyai antracittelepes felsõkarbon összlet a Siklósbodony 1. és a Bogádmidszent 1. sz. fúrás tükrében (The Upper-Carboniferous anthracite sequence in the boreholes Siklósbodony 1. and Bogádmidszent 1). - MÁFI Annual Report 1973, pp. 323-361.

Jámbor, Á. 1969: Karbon képzõdmények a Mecsek és a Villányi-hegység közötti területen (Carboniferous formations in the area between the Mecsek and Villány-hills). - MÁFI Annual Report, 1967, pp. 215-221.

Jámbor, Á. 1998: A Tiszai Nagyszerkezeti Egység karbon üledékes képzõdményei rétegtanának ismertetése (Overview on stratigraphic geology of Carboniferous sedimentary formations of the Tisza unit). - In: Magyarország geológiai képzodményeinek rétegtana - MÁFI-MOL, Budapest, pp. 173-185.

Kassai, M. 1973: A délkelet-dunántúli paleozoós rétegsorok fáciesmeghatározásának problémái (Questions in facies identification of Paleozoic columns in SE Transdanubia). - Földtani Közlöny, 103/3-4, pp. 389-402.

Kassai, M. 1980: A DK-dunántúli felsõkarbon képzõdmények elterjedésének meghatározása a szeizmikus és tellúrikus adatok alapján (Determination of the extent of Upper Carboniferous formations in SE Transdanubia). - MÁFI Annual Report, 1978, pp. 301-307. 
Kassai, M 1983: A felsõ karbon elterjedése és nyersanyagkutatási perspektívái a Dél-Dunántúlon (The extent and raw material potential of the Upper Carboniferous formations in South Transdanubia). - Földtani Kutatás, 26/2, pp. 53-56.

Koch, J. 1997: Upper limits for vitrinite and bituminite reflectance as coalification parameters International Journal of Coal Geology, 33, pp. 169-173.

Kwiecinska, B., P. Slawomira, M. Krzesinska, B. Pilawa 2006: Physical properties of shungiteInternational Journal of Coal Geology (article in press).

Majoros, Gy. 2000: A few reflections on the telluric conductance map of Transdanubia. Geophysical Transactions, 43, pp. 291-296.

Nemesi, L., I. Hobot, G. Varga 1985: Telluric and magnetotelluric information about the geological structure of Transdanubia. - Acta Geod. Geoph. Mont. Hung., 20, pp. 135-150.

Nemesi, L., G. Varga, A. Madarasi 2000: Telluric map of Transdanubia. - Geophysical Transactions, 43, pp. 169-204.

Pilkington, M., R.A.F. Grieve 1992: The geophysical signature of terrestrial impact craters. - Reviews of Geophysics, 30, pp. 161-168.

Ravaszné Baranyai, L. 1971: Jelentés a Bogádmidszent 1. sz. fúrás ásvány-kõzettani vizsgálatáról (Report on the minerologic-petrographic study of the borehole Siklósbodony 1). - Report-MÁFI Archives, Manuscript, $170 \mathrm{p}$.

Soós, I., Á. Jámbor 1960: Növénymaradványos felsõkarbon kavicsok a Mecsek hegység Helvéti kavicsösszletébõl (Upper Carboniferous gravel with plant remains from the Helvetian gravel beds in the Mecsek mountains). - Földtani Közlöny, 90/4, pp. 456-458.

Szakmány, Gy., S. Józsa 1994: Rare pebbles from the Miocene conglomerate of Mecsek Mts, Hungary. - Acta Mineralogica-Petrographica, 35, pp. 53-64.

Szederkényi, T. 1998: A Dél-Dunántúl és az Alföld kristályos aljzatának rétegtana (Stratigraphic geology of the basement of South Transdanubia and the Great Hungarian Plain). - In: Magyarország geológiai képzõdményeinek rétegtana - MÁFI-MOL, Budapest, pp. 93-106.

Varga, A. 2000: A dél-dunántúli felsõ-karbon homokkövek kõzettani és geokémiai vizsgálatának eredményei (Results of the petrographic and geochemical study of Upper Carboniferous sandstones in South Transdanubia). - Eötvös Loránd University, Budapest, Manuscript, $71 \mathrm{p}$.

Varga, A., Gy. Szakmány, S. Józsa, Z. Máthé 2001: A nyugat-mecseki alsó-miocén konglomerátum karbon homokkõ kavicsainak és a Tésenyi Homokkõ Formáció képzõdményeinek petrográfiai és geokémiai összehasonlítása (Petrographic and geochemical comparison of the Carboniferous sandstone gravels found in the Lower Miocene conglomerate in West Mecsek and the formations of Téseny sandstone formation). - Földtani Közlöny, 131/1-2, pp. 11-26.

Varga, G. 1977: Jug paleozoós, jolt vested képzõdmények mutates a Dél-Dunántúlon (Exploration of Late Paleozoic conductive formations in South Transdanubia). - Report of Eötvös Loránd Geophysical Institute of Hungary, Manuscript, ELGI Archives, Budapest, $23 \mathrm{p}$.

Wilks, K.R., M. Mastalerz, R.M. Bustin, J.V. Ross 1993 The role of shear strain in the graphitization of a high-volatile bituminous and an anthracitic coal. - International Journal of Coal Geology, 22, pp. 247-277. 